\title{
A MEDIUM-SPATIAL SCALE DISTRIBUTION PATTERN OF PSEUDOSCORPIONIDA (ARACHNIDA) IN A GRADIENT OF TOPOGRAPHY (ALTITUDE AND INCLINATION), SOIL FACTORS, AND LITTER IN A CENTRAL AMAZONIA FOREST RESERVE, BRAZIL*
}

\author{
AGUIAR, N. O. ${ }^{1}$, GUALBERTO, T. L. ${ }^{1}$ and FRANKLIN, E. ${ }^{2}$ \\ ${ }^{1}$ Universidade Federal do Amazonas, UFAM, Manaus, Amazonas, Brazil \\ ${ }^{2}$ Dept. of Entomology, Instituto Nacional de Pesquisas da Amazônia, INPA, UFMA, Manaus, Amazonas, Brazil \\ Correspondence to: Elizabeth Franklin, INPA/CPEn, Avenida André Araújo, 2936, Petrópolis, \\ C. P. 478, CEP 69011-970, Manaus, AM, Brasil, e-mail: beth@inpa.gov.br
}

Received November 26, 2004 - Accepted May 19, 2005 - Distributed August 31, 2006

(With 4 figures)

\begin{abstract}
In Amazonia, nothing is known about the distribution of the invertebrates on a medium-spatial scale pattern. In a trail system of $64 \mathrm{~km}^{2}$ at Ducke Reserve, we sampled 72 transects using the hand-sorting method and Berlese-Tullgren extraction. The reserve possesses ecosystems of "terra-firme" forest and the trail system represents a gradient of topographic soil factors and vegetation, avoiding categorizations. Considering the abundance and diversity of Pseudoscorpionida, we investigated the relation of the community to environmental factors tested (topography, clay percentage, litter, and soil $\mathrm{pH}$ ), to the two major drainage basins of the reserve, and if these invertebrates can be used as biological indicators to monitor changes. We registered two species for the first time in the reserve, increasing the known diversity to 17 species. The lack of correlation with the predictor variables and the large home range, indicate that pseudoscorpions are not good biological indicators in the reserve. As the eastern and western watersheds are not separate management units for the community, our results show that they are generalist predators. In spite of our results and lack of knowledge concerning their biology, life history and taxonomy, pseudoscorpions are cosmopolitan and easy to find and measure. Compared with previous studies in the reserve, they have a consistent pattern of abundance and diversity throughout the years showing the stability of the community which can be checked mainly by comparison with environmental changes that would occur in the reserve. An investigation on a medium-spatial scale pattern and over a long-term period including other habitats, and also other predictor variables, like humidity, the structure of the vegetation and canopy closure, will be necessary to reinforce the observed tendencies.
\end{abstract}

Keywords: central Amazonia, soil arthropods, medium-spatial scale, biological indicator Pseudoscorpionida.

\section{RESUMO}

\section{Padrão de distribuição em escala meso-espacial de Pseudoscorpionida (Arachnida) em um gradiente de topografia (Altitude e Inclinação), Fatores do solo e serapilheira numa reserva Florestal da Amazônia Central, Brasil}

Na Amazonia, nada é conhecido sobre o padrão de distribuição de invertebrados em escala meso-espacial. Em um sistema de trilhas de $64 \mathrm{~km}^{2}$ na Reserva Ducke, foram coletados invertebrados em 72 parcelas por meio de coleta manual e método de Berlese-Tullgren extraction. A reserva possui ecossistemas de florestas terra-firme e as trilhas representam um gradiente de topografia, fatores do solo e vegetação,

\footnotetext{
* Part of a Master's Degree dissertation of the second author.
} 
evitando categorizações. Considerando a abundância e a diversidade de Pseudoscorpionida, investigouse a relação da comunidade com os fatores ambientais (topografia, porcentagem de argila, serapilheira e $\mathrm{pH}$ do solo), com as duas bacias de drenagem (Leste e Oeste) da reserva, e se esses invertebrados podem ser usados como indicadores biológicos para monitorar mudanças. Foram registradas duas espécies pela primeira vez na reserva, aumentando a diversidade para 17 espécies. A falta de correlação com as variáveis preditoras, significando que os pseudoscorpiões não são sensíveis aos fatores ambientais analisados, e a ampla distribuição, mostrando que estão igualmente distribuídos, não os apontam como bons indicadores biológicos na reserva. A falta de diferença entre as comunidades das duas bacias de drenagem indica que esses invertebrados são predadores generalistas. Apesar desses resultados e da falta de conhecimentos sobre a biologia, a história de vida e a taxonomia, os pseudoscorpiões são cosmopolitas, fáceis de encontrar e de medir. Comparando com estudos prévios na reserva, observou-se que possuem um padrão consistente de abundância e diversidade através dos anos, mostrando a estabilidade da comunidade, o que pode ser comprovado principalmente pela comparação com as mudanças ambientais que poderão ocorrer na reserva. Para reforçar as tendências aqui observadas, será necessária uma investigação em escala meso-espacial e de longa duração, compreendendo outros hábitats e outras variáveis preditoras como a umidade, a estrutura da vegetação e a cobertura da copa.

Palavras-chave: Amazonia Central, artrópodos do solo, escala meso-espacial, indicadores biológicos, Pseudoscorpionida.

\section{INTRODUCTION}

Knowledge of Pseudoscorpions is still very fragmentary and the taxonomic situation, particularly in South America, is unsatisfactory (Mahnert \& Adis, 2002). Most species inhabit the soil and litter, feed on small arthropods, such as mites, beetle larvae or springtails, but some larger species may also attack ants. The distribution of Pseudoscorpions in the Amazonia region differs from one habitat to another, caused by ecological factors such as soil, vegetal cover, temperature and humidity (Adis, 1981; Adis \& Mahnert, 1990; 1993, Adis et al., 1988; Mahnert \& Adis, 1985; Moraes, 1985; Aguiar, 2000; Aguiar \& Bührnheim, 1998; 2003).

In a compilation of existing criteria from the literature to choose faunal indicator taxa, Hilty \& Merelender (2000) found that the main shortcoming of the invertebrates reviewed included failure to establish correlation between changes in the indicator taxa and the ecosystem and selecting taxa at a high taxonomic level, which potentially increases the number of inappropriate species and variables in the data. The suggested criteria for an indicator are the baseline information (clear taxonomy, biology and life history studied, tolerance levels known, and correlation to ecosystem) and local information (cosmopolitan distribution, small home range size). Other indicators are niche and life history characteristics (early warning and functional over range of stress, detectable trends, low variability, specialist, easy to find and measure).

The Reserve chosen for this investigation (Reserva Florestal Adolpho Ducke) has a total area of 10,000 hectares with ecosystems representative of the "terra-firme" (dryland) forest of Central Amazonia, and a huge system of trails that reach $64 \mathrm{~km}^{2}$, propitiating a medium-spatial scale pattern study. Some studies were developed on pseudoscorpions at the reserve (Morais, 1985; Adis \& Mahnert, 1993). However, these studies were concentrated in the northwestern part, using less than a $1 / 5$ of the total area. According to May (1994), much of our attention is focused on the ecology and behavior of individuals or small groups, typically in a time factor of 3 years or less and spatial scale of $10 \mathrm{~m}$ or less. He says that these studies are entirely appropriate to the questions being asked, but derive more from the financial and time constraint of grants than from careful assessment of the spatial scales that govern the system in question. Nevertheless, most reserves consist of several thousand to a million hectares. The Ducke Reserve has a gradient involving the entire pattern of topography (altitude and slope), soil factors and vegetation types that include the whole area, avoiding habitat categorizations and small-scale pattern inventories. A central ridge 
divides the reserve into two hydrographic basins, one draining to the West towards the Rio Negro, and the other draining to the East towards the Amazonia River (Ribeiro et al., 1999). Each watershed has several drainage basins that are isolated from each other within the reserve.

In Central Amazonia, nothing is known about the distribution of the invertebrate community in a medium-spatial scale pattern, and we are using the predatory group of pseudoscorpions as an example. Using its abundance and diversity, we asked the following questions: 1) Are there differences between this medium-spatial scale pattern study and the small-spatial scale studies that have already been done on pseudoscorpions in the Amazonia region?; 2) Are the pseudoscorpions related to a gradient of topography, clay percentage, litter, and $\mathrm{pH}$ ?; 3) Are there differences between the abundance and diversity between the two major drainage basins?; and 4) Can the abundance and diversity of species be used as indicators to monitor changes in the reserve?

\section{METHODS}

Fieldwork was conducted between September, 2001 and May, 2002 at Reserva Florestal Adolpho Ducke. The sampling period was mainly concentrated in the wet season (DecemberMay). Only two of the 72 transects were sampled in September (dry season). The reserve has topographic and edaphic variation typical of many areas in central Amazonia and has a total area of 10,000 hectares situated northwest of Manaus, at $\mathrm{km} 26$ on the Manaus-Itacoatiara Highway $\left(3^{\circ} 00^{\prime} \mathrm{S}, 59^{\circ} 55^{\prime} \mathrm{W}\right)$ (Fig. 1). It is a moderately rugged terrain (elevation 30-180 m.a.s.l.). The nutrient-poor soils are classified as yellow clayed latosol, located at the plateaus and clay-sand soil located on the ridges, which grades to sandy soils (hidromorphic podzol) in the valleys (Chauvel et al., 1987; Ribeiro et al., 1999). The vegetation is "terra-firme" non-flooded rain forest with a closed canopy, and undergrowth characterized by abundant sessile palms, such as Astrocarium

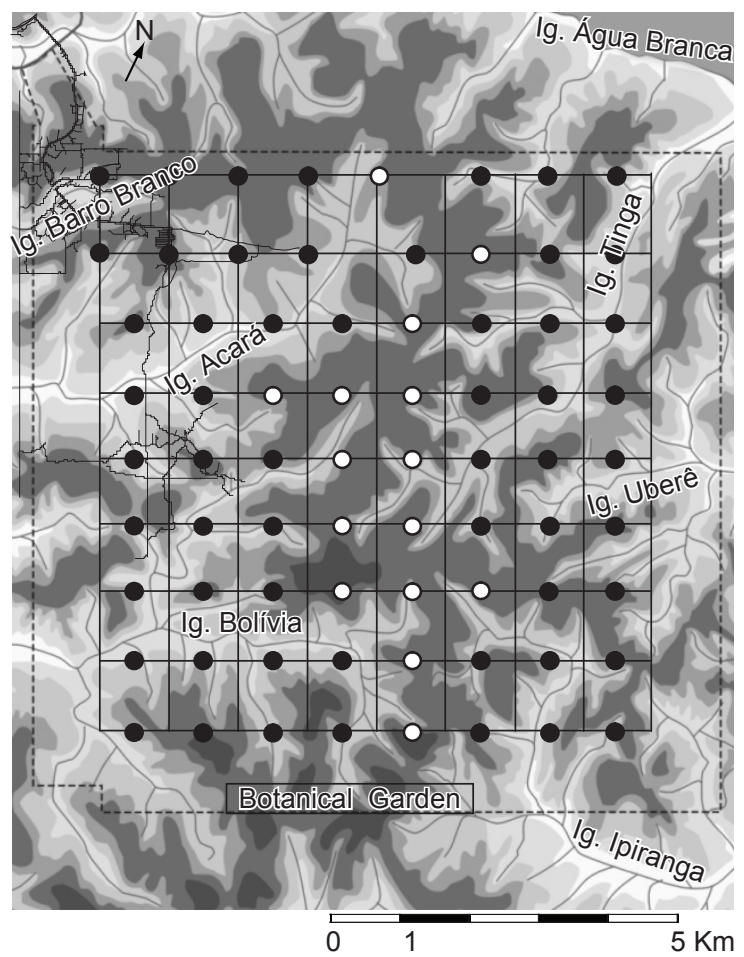

Fig. 1 - Map of "Reserva Florestal Adolpho Ducke" showing the 9 trails (fine continuous lines) and the position of the 72 plots (white dots indicate those situated on the central plateau separating both watersheds basins). Shadings indicate gradients in altitude from the lowest areas (lightest color, $<40$ m. a. s. 1.) to the darkest areas (darkest shading, $>120$ m.a.s.1.). The limit of the reserve is shown by the dotted line. 
spp and Attalea spp. The canopy height of trees is generally 30-37 m with some reaching 40-45 m. The mean temperature is $26{ }^{\circ} \mathrm{C}$ and the mean annual rainfall is $1,362 \pm 400 \mathrm{~mm}$, with a short dry season between July and September (MarquesFilho et al., 1981).

In 2001/2002, a system of $9 \mathrm{~N}-\mathrm{S}$ and $9 \mathrm{E}-\mathrm{W}$ trails was installed in the reserve. The trails are separated $1 \mathrm{~km}$ from each other, covering an area of $64 \mathrm{~km}^{2}$ (6,400 ha). The smallest distance between the trails and the edge of the forest was $1 \mathrm{~km}$. A system of 72 permanent transects was installed along the trail system to cover the habitat variation in the reserve systematically (Fig. 1). Each transect was $250 \mathrm{~m}$ long by $6 \mathrm{~m}$ wide $(0.15 \mathrm{ha})$ and followed the isoclines to minimize within-transect soil variation. A professional surveyor measured the altitude and transect composition. The slope was measured at every $50 \mathrm{~m}$ along each transect, for a total of 6 points per transect. The Soil and Plant Laboratory of INPA measured the chemical and physical data of the soil.

We used two sampling methods in order to have representatives from the litter (hand-sorting), and from the litter + mineral soil (Berlese-Tullgren extraction). In both methods, we took a total of 360 sub-samples, obtaining 5 at each one of the 72 transects. Each one of the 72 transects of our sampling design had a dimension of 0.15 ha, making a total of 10.8 ha of surveyed area systematically placed in 6,400 ha. For the handsorting method, we used 5 sub-samples of $0.25 \mathrm{~m}^{2}$ of litter, taken at each $50 \mathrm{~m}$, to sort manually in the laboratory. We used these five replicates to estimate the amount of litter (dry weight) of the parcels. To cover a larger area, we took the samples from Berlese-Tullgren at each $12.5 \mathrm{~m}$, using cores $(3.5 \times 3.5 \mathrm{~cm})$ introduced $5 \mathrm{~cm}$ deep into the soil profile. To reduce the scientist-hours of sorting in the laboratory, four consecutive soil cores were joined from each transect to form a compound subsample, totaling 5 compound sub-samples, and each one making up a total area of $0.0049 \mathrm{~m}^{2}$. The total area covered by the compound sub-samples in each transect was $0.0245 \mathrm{~m}^{2}$. The animals were fixed in $70 \%$ alcohol and identified at species levels. We averaged the data from the 5 sub-samples in each transect for analysis. Five exploratory variables were measured: topography (altitude and inclination), clay percentage, the amount of litter $(\mathrm{g}), \mathrm{pH}\left(\mathrm{H}_{2} \mathrm{O}\right)$ of the soil and clay percentage. The characteristics of transects established at the reserve were (mean and range of the observed values): altitude (76 m.a.s.1.; 39.4-109 m.a.s.1.), inclination $(9.9 ; 0.7-27)$, percentage of clay (49.2; $2-88)$, litter (222.1 g; 116.9-482.6 $\mathrm{g})$ and $\mathrm{pH}\left(\mathrm{H}_{2} \mathrm{O}\right)$ (4; 3.4-4.8).

The analyses used data from the two sampling methods combined. To meet assumptions of normality, we transformed the mean density of the invertebrates as $\ln (x+1)$. To avoid the use of intercorrelated predictor variables in the same regression model, we made a correlation analysis (Pearson) with the Bonferroni option, considering $r>0.4$ and $p<0.05$. We used a multiple regression analysis to explore the factor or factors accounting for the observed variability in abundance of the most abundant species, as well as for the species richness in the Pseudoscorpionida community. We excluded outliers from the analysis. The clay percentage and $\mathrm{pH}\left(\mathrm{H}_{2} \mathrm{O}\right)$ had a strong correlation with the altitude (Pearson $r=0.841, p<0.001$, and $r=-0.438, p<0.001$, respectively). The clay percentage also had a strong correlation with the $\mathrm{pH}$ $\left(\mathrm{H}_{2} \mathrm{O}\right)$ (Pearson $\left.r=-0.556, p<0.001\right)$. Therefore, we chose altitude, inclination and litter to make the regression model. We have considered possible type II errors (the probability of accepting the null hypothesis when it is false). We also plotted the partial regression coefficient in our figures to show how two variables are related if the effects of the other two variables are removed from their relationship (Magnusson \& Mourão, 2003).

To observe the differences between the two watersheds and similarities among samples, we used data from the hand-sorted samples, the Berlese-Tullgren samples and the two sampling methods combined. The differences in species richness between the two hydrographic (West and East) basins were assessed using t-tests. The categorization of the transects was done using the central plateau as a reference resulting in 34 transects in the Western basin and 32 on the Eastern side. Using binary data, we made correlations to calculate measures of similarity and distance. To calculate a matrix of a similar coefficient (Jaccard's index), we produced a matrix using the data scored as 0 (absence) or 1 (presence) of species. The species were displayed in lines and the samples (each sampling method collected 
in the Western or Eastern basin and plateau) in columns. The columns of the data matrix were clustered and displayed in a tree. We produced a tree by cluster analysis of the data matrix, using the Euclidean distance coefficient (root-mean-squared differences) and the UPGMA clustering method. The statistical analyses were done with Systat 8.0.

\section{RESULTS}

\section{Variation in species richness and abundance}

By combining two sampling methods, we registered a richness of ten species, seven genera and four families of Pseudoscorpionida (Table 1 and 2). We registered seven species in the litter (hand sorted) and eight in the litter + mineral soil (Berlese-Tullgren extraction) (Table 1). Two of these species were not previously recorded from the reserve: T. irmleri (two adults specimens, male and female), and $T$. amazonicus (one male adult). These registers increase the known richness to 17 identified species (Table 2), with 14 of them considered edaphics. T. amazonicus, T. rotundimanus and $M$. tridens were unique for the Berlese samples (litter and mineral soil), the first occurring with only one individual. T. irmleri and I. tenuis were unique for hand-sorted samples (litter), both with low registers of abundance. A standard deviation is a useful parameter for only describing the variability in a population of measurements if the population of measurements has a frequency distribution that conforms to a theoretical distribution called "normal" (Magnusson \& Mourão, 2003). Therefore, as our data can not be considered normal, we represented the variation between transects for the six more abundant species of pseudoscorpions plotting symmetrical dot abundance in Fig. 2, combining the results of both sampling methods. The figure shows that the six species of pseudoscorpions are distributed along the huge gradient of $64 \mathrm{~km}^{2}$, represented by the 9 trails (eight transects per trail) included in our sampling design.

Comparing the species richness of combining both sampling methods along each transect of the 9 trails, the registers per transect oscillated between 0 to 7 species. Considering the 72 transects, the most frequent numbers of species registered per transect were 3 (in 18 transects), 4 (in 16 transects) and 5 (in 15 transects) making a total of $68 \%$ of the surveyed transects. Considering the first transect as the one situated on the first trail in the northern part of the reserve (Fig. 1), and moving eastwards, we sampled 5 species in the first transect, we accumulated three more species in the second transect, and another one in the third transect, resulting in a cumulative number of 9 species. The species area curve stabilized with 26 transects (which corresponds to approximately $18 \mathrm{~km}^{2}$ ) to reach the total of 10 species obtained in this study.

TABLE 1

Species richness, abundance with mean and standard deviation of Pseudoscorpionida in 72 plots of $250 \mathrm{~m}$, in a trail system of $64 \mathrm{~km}^{2}$ at Ducke Reserve. * New record for the reserve.

\begin{tabular}{|l|c|c|c|c|c|c|}
\cline { 2 - 7 } \multicolumn{1}{c|}{} & \multicolumn{2}{c|}{ Hand-sorting } & \multicolumn{2}{c|}{ Berlese } & \multicolumn{2}{c|}{ Total } \\
\cline { 2 - 7 } \multicolumn{1}{c|}{} & $\mathbf{N}$ & $\mathbf{\%}$ & $\mathbf{N}$ & $\mathbf{\%}$ & $\mathbf{N}$ & \% \\
\hline Ideobisium schusteri & 319 & 48.4 & 5 & 3.3 & 324 & 40.0 \\
\hline Brazilatemnus browni & 138 & 20.9 & 25 & 16.7 & 163 & 20.1 \\
\hline Microblothrus tridens & 0 & 0 & 96 & 64.0 & 96 & 11.9 \\
\hline Albiorix gracilis & 80 & 12.1 & 2 & 1.3 & 82 & 10.1 \\
\hline Pseudochthonius homodentatus & 66 & 10.0 & 6 & 4.0 & 72 & 8.9 \\
\hline Tyrannochthonius minor & 51 & 7.7 & 8 & 5.3 & 59 & 7.3 \\
\hline Tyrannochthonius rotundimanus & 0 & 0 & 7 & 4.7 & 7 & 0.9 \\
\hline Ideoblothrus tenuis & 3 & 0.5 & 0 & 0 & 3 & 0.4 \\
\hline Tyrannochthonius irmleri* & 2 & 0.3 & 0 & 0 & 2 & 0.2 \\
\hline Tyrannochthonius amazonicus $*$ & 0 & 0 & 1 & 0.7 & 1 & 0.1 \\
\hline Total & 659 & - & 150 & - & 809 & - \\
\hline \% & 81.5 & - & 18.5 & - & 100 & - \\
\hline Number of species & 7 & - & 8 & - & - & - \\
\hline
\end{tabular}


TABLE 2

Species identified at Reserva Florestal Adolpho Ducke. ${ }^{\mathrm{E}}$ Edaphic species; ${ }^{\mathrm{T}}$ Trunk species.

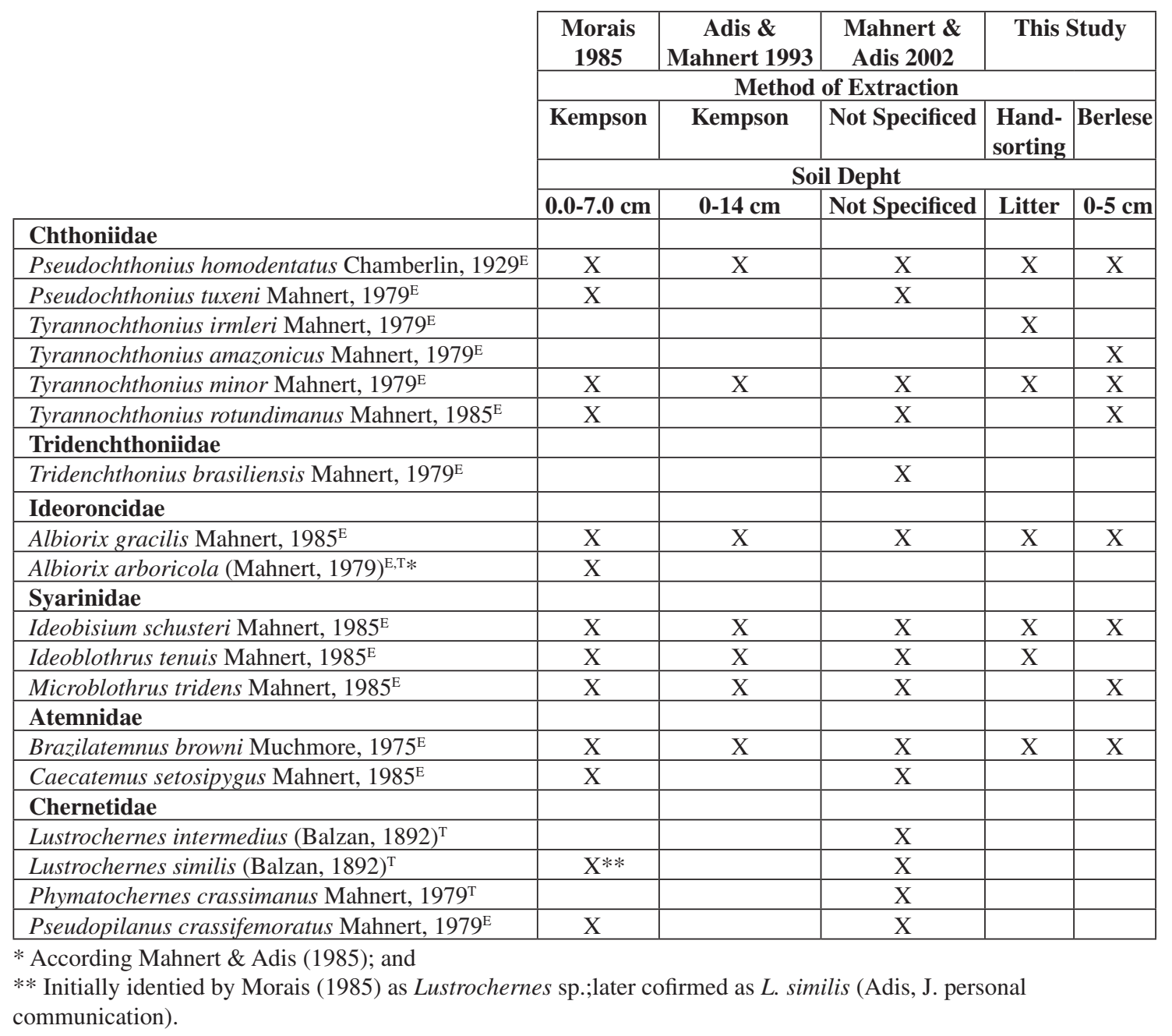

From a total of 809 individuals, we registered $81.5 \%$ in the litter of the hand-sorted method. The most abundant species in the litter were I. schusteri (48\%), B. browni (21\%), A. gracilis (12\%). In the Berlese-Tullgren samples, two species reached the highest dominance: $M$. tridens $(64 \%)$ and B. browni (17\%) (Table 1).

\section{Relation with the predictor variables}

Considering the 6 most abundant species (Table 1), none of the predictor variables significantly affected species abundance of $B$. browni, A. gracilis, and P. homodentatus (Table 3 ). Considering the effect of the altitude, the inclination and the amount of litter on the distribution of
I. schusteri, the overall probability of the regression model was not significant $(\mathrm{P}=0.136)$. Therefore, when the effect of the inclination and the amount of litter was removed, we detected the effect of the altitude $(\mathrm{P}=0.045)$. The overall model was close to $8 \%$ of the variation in the abundance (multiple $\left.\mathrm{R}^{2}=0.079\right)$. Concerning the plotting predictor and dependent variables (Fig. 3), the observed tendency was an increase in the abundance of I. schusteri from the valleys towards the plateaus.

The inclination had an effect on the distribution of M. tridens and T. minor. Although the overall values of probability had not been significant $(\mathrm{P}=$ 0.195 and $\mathrm{P}=0.088$ ) for these two species, the values of partial significance were close to a type 

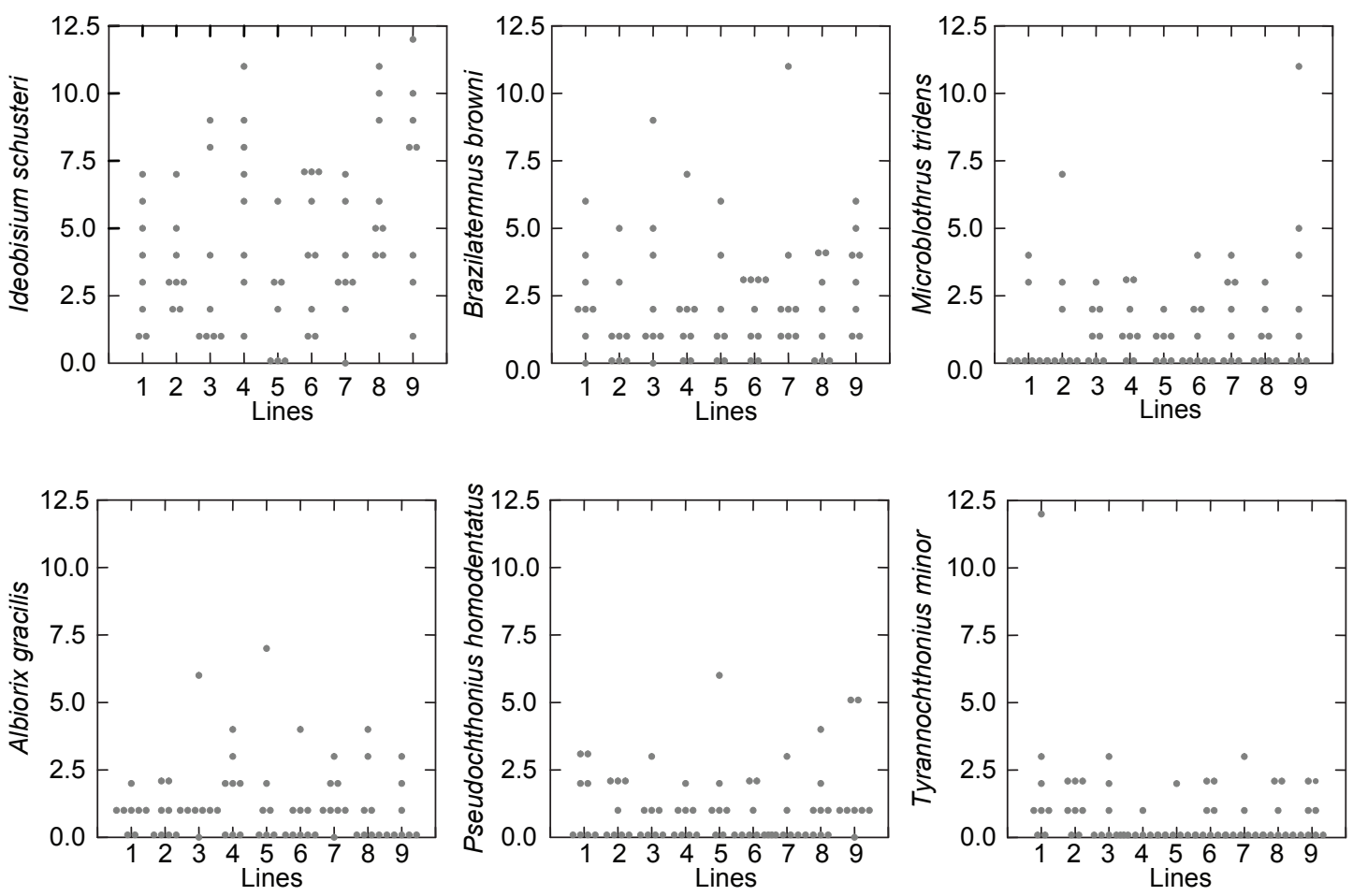

Fig. 2 - Symmetrical dot displays of the abundance of Pseudoscorpionida in a system of 9 trials (eight plots/trail) reaching an area of $64 \mathrm{~km}^{2}$ at the Ducke Reserve. The data included both methods of sampling (hand-sorting and Berlese-Tullgren).

TABLE 3

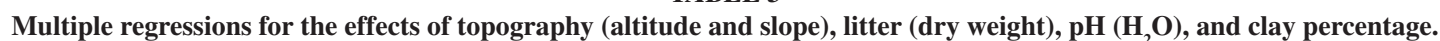

Dependent variables tested were: total number Pseudoscorpionida species, Ideobisium schusteri, Brazilatemmus browni, Microblothrus tridens, Albiorix gracilis, Pseudochthonius homodentatus and Tyrannochthonius minor. The data included both methods of sampling (hand-sorting and Berlese-Tullgren).

\begin{tabular}{|l|l|c|c|c|r|r|r|}
\hline \multicolumn{1}{|c|}{$\begin{array}{c}\text { Dependent } \\
\text { variables* }\end{array}$} & $\begin{array}{l}\text { Predictor } \\
\text { variables }\end{array}$ & $\mathbf{R}^{2}$ & $\mathbf{P}$ & $\mathbf{F}$ & $\begin{array}{c}\text { Regression } \\
\text { coeficient }\end{array}$ & $\mathbf{T}$ & P (partial) \\
\hline $\begin{array}{l}\text { Ideobisium } \\
\text { schusteri }\end{array}$ & Altitude & 0.079 & 0.136 & 1.914 & 0.005 & 2.044 & $\mathbf{0 . 0 4 5}$ \\
& Inclination & & & & -0.002 & -0.303 & 0.763 \\
& Litter & & & & $<0.001$ & 0.319 & 0.751 \\
\hline Microblothrus & Altitude & 0.069 & 0.195 & 1.612 & 0.002 & 1.869 & 0.101 \\
tridens & Inclination & & & & $<0.001$ & 0.953 & $\mathbf{0 . 0 6 6}$ \\
& Litter & & & & 0.007 & 1.663 & 0.344 \\
\hline Tyrannochthonius & Altitude & 0.094 & 0.088 & 2.279 & 0.001 & 0.776 & 0.441 \\
minor & Inclination & & & & 0.005 & 1.962 & $\mathbf{0 . 0 5 4}$ \\
& Litter & & & & -0.001 & -1.195 & 0.236 \\
\hline
\end{tabular}

* Only variables with significant $(\mathrm{P}<0.05)$ for the whole or partial model effect and values of possible type II error are give (see in bold).

II error $(\mathrm{P}=0.066$ and $\mathrm{P}=0.054)$. The overall model showed around $7 \%$ and $9 \%$ of the variation in the abundance (multiple $\mathrm{R}^{2}=0.069$ and 0.094), respectively. The increase in the slope positively affects the abundance of both species (Fig. 3).

\section{Distribution and composition of species between the two major drainage basins}

We did not find a significant difference between the basins with regards to species richness combining both sampling methods (mean $\pm \mathrm{SD}$; 

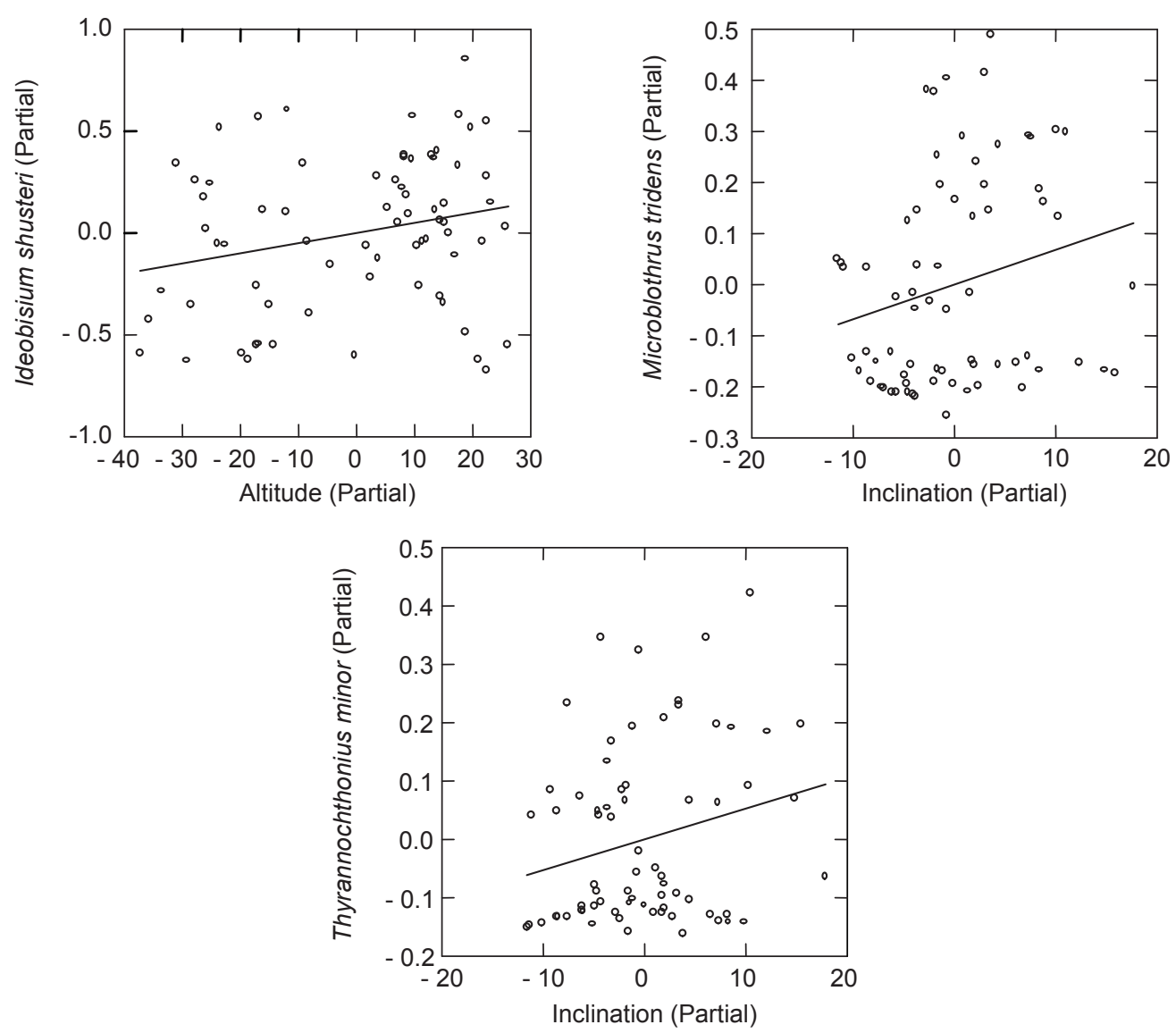

Fig. 3 - Partial regression of Ideobisium schusteri on altitude, and of Microblothrus tridens and Tyrannochthonius minor on inclination, in 72 plots of $250 \mathrm{~m} \times 6 \mathrm{~m}$, located in a system of 9 trails (eight plots/trail) reaching an area of $64 \mathrm{~km}^{2}$ at Ducke Reserve. The data included both methods of sampling (hand-sorting and Berlese-Tullgren).

Eastern: $4.1 \pm 1.6$; Western: $3.4 \pm 1.8$ species; $\mathrm{t}=-0.736 ; \mathrm{df}=54.4, \mathrm{p}=0.465)$. We also observed the same tendency separating the hand-sorting method (mean \pm SD.; Eastern: $3.1 \pm 1.2$; Western: $3.1 \pm 1.3$ species; $\mathrm{t}=0.077 ; \mathrm{df}=54.7, \mathrm{p}=0.939$ ), and Berlese-Tullgren extraction (mean \pm SD.; Eastern: $1.0 \pm 1.0$; Western: $1.3 \pm 1.4$ species; $\mathrm{t}=-1.103 ; \mathrm{df}=60.8, \mathrm{p}=0.275)$. This result reinforces what is represented in Fig. 2. The species were distributed in the following way: A. gracilis, B. browni, I. schusteri, M. tridens, P. homodentatus, T. minor (central plateau and both basins); I. tenuis, T. irmleri, T. rotundimanus (Eastern and Western basins), and T. amazonicus (Western basin).

Jaccard's similarity index shows two clusters (Fig. 4). One consists of the species sampled by hand-sorting and the other by Berlese-Tullgren extraction. Each is formed by fauna from the two hydrographic watersheds and the central plateau.

\section{DISCUSSION}

\section{The differences between this medium-spatial scale pattern study and the small-spatial scale studies known from the Amazonia region}

A list of 80 species of pseudoscorpions from Amazonia is provided by Mahnert \& Adis (2002). In the soil and litter of Amazonia, a total diversity of 24 species is known (Mahnert \& Adis, 1985). In the neighboring areas of Manaus, Central Amazonia, the diversity of pseudoscorpions is moderately known and most studies developed upto-date can be considered as a small-scale pattern. Using arboreal fotoeclectors, Adis (1981) registered 15 species in the flooded forest of "igapó", with 5 of them as litter inhabitants. Using the Kempson apparatus to extract the litter and soil to a $14 \mathrm{~cm}$ depth, representing an area of $0.21 \mathrm{~m}^{2}$ and during 
6 months in mixed water flooded forest, Morais et al. (1997) registered 3 species in the soil and $95.2 \%$ of them were represented by T. amazonicus. Using the same methodology in a secondary forest, sampling only one period per season (dry and wet), Adis \& Mahnert (1990) registered 9 species during the dry season and 7 in the wet season. The same methodology was used in a primary forest of the Ducke Reserve and in a primary forest on white sand soil ("Campinarana") by Adis \& Mahnert (1993). At the "Campinarana" forest, 7 species were registered, with 534 and $481 \mathrm{ind} / \mathrm{m}^{2}$ captured in the dry and wet season, respectively. At the Ducke Reserve, 7 species were registered with $1,703 \mathrm{ind} / \mathrm{m}^{2}$ and $1,135 \mathrm{ind} / \mathrm{m}^{2}$ captured in the dry and wet season, respectively. M. tridens, I. schusteri and I. tenuis were the most abundant species (74-78\% of the total catch), followed by T. minor, P. homodentatus (12-13\%), and B. browni and $A$. gracilis (10\%).

In a small-scale pattern study developed in several transects of dryland primary forest in the upper course of the Urucu River, Central Amazonia, Aguiar (2000) and Aguiar \& Bührnheim (2003) registered the highest diversity of Pseudoscorpionida (14 species) in the soil, litter and undergrowth vegetation. The author used the Berlese extraction and hand-sorting methods in a relatively long-term period of time from 1991 to 1995. Aguiar (2000) registered T. amazonicus for the first time in terra firme. In contrary to the high abundance that was registered by Morais et al. (1997) in floodplain forests, in dryland forests this species showed very low abundance and frequency in the litter and suspended soil of undergrowth vegetation (palm trees).

Another small-scale pattern study with a relatively long-term period of 13 months of sampling was made in the Northwestern part of the Ducke Reserve by Morais (1985). From these 13 month periods of sampling, the author selected 6 monthly samples in August, 1982 and June, 1983 to study the fauna of pseudoscorpions. The samples were introduced $7 \mathrm{~cm}$ deep into the soil (Kempson extraction). Twelve identified species and one morphospecies (Lustrochernes sp.) were registered. The morphospecies (Lustrochernes sp.) is now confirmed to be L. similis (Balzan, 1892) (Adis, J., personal communication). The author added up the total for two species (A. gracilis and $A$. arboricola). A higher abundance was registered in the dry season $\left(350 \mathrm{ind} / \mathrm{m}^{2}\right)$ compared to the rainy season $\left(181.2 \mathrm{ind} / \mathrm{m}^{2}\right)$. M. tridens was the most abundant (54\% of the total catch), followed by $T$. minor (17.5\%) and B. browni (12\%). Caecatemus setosipygus, Pseudopilanus crassifemoratus, Pseudochthonius tuxeni and Lustrochernes sp. (=L. similis), classified as rare by the author (1.4-4.1\% of dominance), were not registered in our study. Even though there was a high abundance in our Berlese samples, we did not register $M$. tridens in the hand-sorting method (litter), indicating that that this specie inhabits the soil below. Using Kempson to extract the animals, Adis \& Mahnert (1993) found that M. tridens occurred in all soil layers $(0-14 \mathrm{~cm})$ of the Ducke Reserve.

Theoretically, the data from Morais (1985) represent about one of our 72 transects. His longterm period of sampling, across both seasons, and

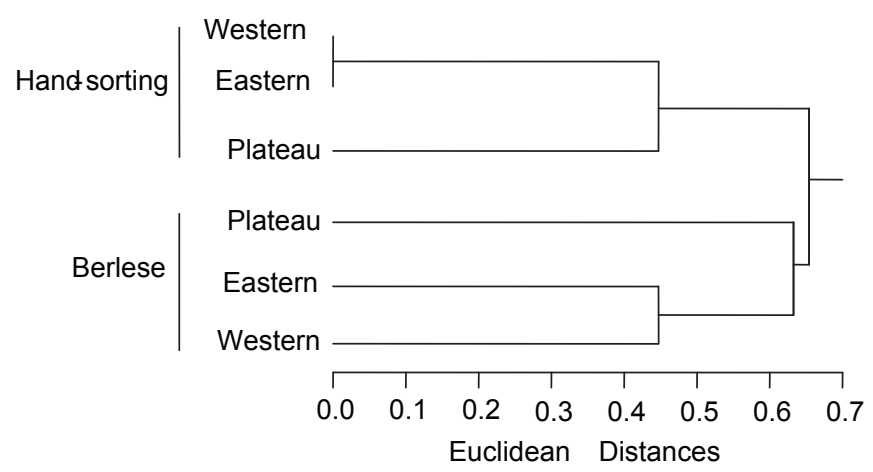

Fig. 4 - Tree produced by cluster analysis, using Euclidean distance coefficient and the UPGMA clustering method, comparing the similarity of ten species of Pseudoscorpionida between the two watersheds and method of sampling (hand-sorting and Berlese-Tullgren). 
reaching deeper layers in the soil, explains the higher diversity compared to our results. Our sampling period was mainly concentrated in the wet season (December-May), period of lowest abundance of pseudoscorpions, and reached $5 \mathrm{~cm}$ deep in the soil. Even though we assume that our extraction efficiency (hand-sorting and Berlese-Tullgren extraction) is not comparable to the Kempson extractor, we are giving two new species not previously recorded from the reserve (T. irmleri and T. amazonicus), increasing the known richness to 17 species.

Richness estimates are highly influenced by rare species (Longino et al., 2002). Taking into consideration the medium-spatial scale of our inventory and that it was necessary to join the sampling of 26 transects to obtain the total species richness, we may say that both above cited species are rare. Our richness per transect $(250 \mathrm{~m})$ varied from 0 to 7 species. The number of registered species stabilized with 26 transects, which corresponds to approximately $18 \mathrm{~km}^{2}$, indicating that the number of 72 transects was sufficient to represent the pseudoscorpions' fauna. Therefore, the rarity of these species is sensitive to the scale and time period in which the inventories are made.

\section{The effect of the gradient of topography, clay percentage, litter, and $\mathrm{pH}$}

The variation in soil texture is closely related to topography in the region of Manaus (Chauvel et al., 1987). In the plateaus, the highest clay percentage and also lower levels of $\mathrm{pH}$ are concentrated, compared to the valleys, which can explain the strong correlation between the clay percentage and $\mathrm{pH}\left(\mathrm{H}_{2} \mathrm{O}\right)$ that we registered. The soils along stream valleys are usually hydromorphic, particularly in flat areas at the bottom of the valleys, where the water drainage is slow (Ranzani, 1980). Considering the six more abundant species, none of the predictor variables significantly affected the species abundance of $B$. browni, A. gracilis, and $P$. homodentatus. The observed tendency for I. schusteri was the increase in its abundance from the valleys towards the plateaus, and for $M$. tridens and $T$. minor, the increase in the slope positively affects their abundance. Therefore, the proportions of explained variance for the equations $\left(\mathrm{R}^{2}\right)$ were very weak, varying from $7 \%$ to $8 \%$. Considering the huge extension of our sampling $\left(64 \mathrm{~km}^{2}\right)$, reaching a gradient of soil, topography and vegetation types in the reserve, the results indicate that the predictor variables were not sufficient to explain the distribution of the species. Despite the low proportion of explained variance, it was clear that these three species responded differently regarding the predictor variables.

Litter production in Central Amazonia is lower in valleys as compared to plateaus (Luizão \& Schubart, 1987). It was experimentally shown in the Ducke Reserve that the patchy distribution of soil surface litter creates a mosaic pattern not only in space, but also in time. This litter patch is leveled within one year at the most, and litterinhabiting decomposer fauna has an important role in the underlying decay process. Only Collembola effectively colonized the additional litter in the first month (Höfer et al., 1996). Collembola is known as a pseudoscorpions' prey and it is to be expected that the abundance of pseudoscorpions increases according to the amount of litter. Therefore, in our study, the multiple regression analysis possibly did not show a significant effect in the amount of litter on the abundance or species richness of pseudoscorpions.

We noticed that the highest abundance of pseudoscorpions in the dry period is a tendency that is repeated in many studies in Central Amazonia (Morais, 1985, Adis \& Mahnert, 1990, Adis \& Mahnert, 1993). As well as the close relation between environmental conditions and spatial distribution of soil animals, there is the fact that soil animals can move, albeit sometimes very slowly, and are able to move in a directed way and make their own choices (Eijackers, 2001). We suppose that the low water availability in the dry season makes some species leave their refuges in more specific micro-habitats and that they can be more easily sampled. Therefore, the humidity of the litter and soil can be chosen as a possible predictor variable to explain their distribution. The abundance and species richness may mirror the availability of prey which changes with the season (Morais, 1985), and these biological factors would be interesting to study, not only the abiotic ones (Adis, J., personal communication).

The complex effects of the geographic variables increase with the size of the area sampled, making interpretation of ecological effects of the predictor variables difficult (May 1994). In our study, we are not referring to meters, but kilometers 
of the surveyed area in order to reach the spatial scales that govern the system in question. The pressing concerns of conservation biology are on longer time scales and vastly greater spatial scales (May, 1994). Therefore, more information is needed to understand how the subtle gradient of topographical variables results in the distinct differences in the community of invertebrates in the litter and soil of the reserve. The BCI Forest Dynamic Project (FDP) was a larger arthropod inventory established in old-growth forest on Barro Colorado Island in a 1,500 ha former hilltop in artificial Gatum lake in the Panama Canal. In 1980, a 50 ha $\left(0.5 \mathrm{~km}^{2}\right)$ permanent transect was laid in this area (Hubbell et al., 2001). Another large arthropod inventory was installed in $\mathrm{La}$ Selva Biological Station, Heredia Province, Costa Rica, that has an area of 1,500 ha of a mosaic of mature lowland rainforest, second growth forest of various ages, and abandoned pasture (McDade et al., 1993). Compared to these projects, each one of the 72 transects of our sampling design has the dimension of 0.15 ha, making a total of 10.8 ha of surveyed area systematically placed in 6,400 ha.

\section{The two major drainage basins and the differences between the abundance and diversity of Pseudoscorpionida}

Despite the aspects considered above, our results clearly show 1) lack of relationship with the predictor variables, 2) non-significant difference between the Eastern and Western watershed with regards to species richness (t-tests), and 3) the great similarity of the community of pseudoscorpions between the watershed basins (Jaccard's similarity measure). Hence, it suggests that predatory pseudoscorpions are not sensitive to the environmental factors analyzed here and are equally distributed along the huge gradient of $64 \mathrm{~km}^{2}$ included in our sampling design. Furthermore, as the Eastern and Western watersheds are not separate management units for the community of pseudoscorpions, these invertebrates can be considered generalist predators in the litter and soil of the reserve. The results found up to now concerning the community behavior of the pseudoscorpions, shows a consistent pattern, for example, regarding the higher abundance of this group in the dry period and number and dominance of species that can be found in a determined environment in different years and using a different sampling methodology, as can be seen comparing our results with those from Morais (1985) and Adis \& Manhert (1993). Consequently, in the same way that the density of the oribatid mite Platynothrus peltifer as a percentage of total oribatids was used as an indicator of forest vitality (Straalen, 1998), the community of Pseudoscorpions can also play an important role in detecting environmental changes for long-term monitoring programs. Many other microhabitats should be investigated in future studies. For example, members of Chernetidae, Withiidae, and Atemnidae live under bark of living or fallen trunks. Endemic species or even genera occur in more specialized habitats (nest of mammals, birds, bees, ants, and termites), canopy of trees, not forgetting the phoretic behaviors of certain species (Mahnert \& Adis, 2002).

\section{The abundance and diversity of \\ Pseudoscorpionida as indicator organisms to monitor changes in the reserve}

Few invertebrate taxa fulfill the multiple criteria for a good biological indicator, as most are highly mobile generalists that lack established tolerance levels and correlations with ecosystem changes (Hilty \& Merelender, 2000). Although the biology, life history and taxonomy of pseudoscorpions are still unsatisfactory, they are easy to find and measure, and have a cosmopolitan distribution. The lack of correlations with the predictor variables, and the large home range detected in the medium-spatial scale pattern study did not show them to be good biological indicator organisms to be used to monitor changes in the reserve. Therefore, is not so simple to define which fraction of the Ducke Reserve can be disturbed and/or monitored without reducing the diversity and abundance of these species. An investigation into a medium-spatial scale pattern and with a long-term period, including other habitats in the forest, and also other predictor variables, like humidity, structure of the vegetation and canopy closure, will be necessary to provide information to reinforce the tendencies observed and reach a definitive conclusion.

Acknowledgments - Financial support came from Project 550409/01-7, CNPq-PNOPG, "Populações e comunidades de invertebrados do solo da Reserva Adolpho Ducke, Manaus, AM", a "Bolsa de Produtividade em Pesquisa/CNPq grant to E. Franklin" and "Project Edital Universal CNPq 47- 
2978/03-9, Reserva Florestal Adolpho Ducke (RFAD): Um modelo amazônico para o inventário e caracterização da biodiversidade" grant to J. A. Rafael. Thanks are due to Dr. J. U. Adis for his help and fruitful discussions as a referee of this paper. The samplings were done in collaboration with two Master degree students, E. Fagundes and R. L. Guimarães, and Dr. J.W. de Morais (INPA). We are grateful to S. Chilson for help in the English version. Most of the trail system was financed by CNPq/PNOPG grant to R. Luizão (INPA). Dr. W. Magnusson (INPA) idealized the experimental design. Dr. A. Lima (INPA) carried out installation of most of the trail system and associated infrastructure.

\section{REFERENCES}

ADIS, J., 1981, Comparative ecological studies of the terrestrial arthropod fauna in Central Amazoniaian inundation-forest. Amazoniaiana, 7(2): 87-173.

ADIS, J. \& MAHNERT, V., 1990, Vertical distribution and abundance of Pseudoscorpion species (Arachnida) in the soil of a Neotropical secondary forest during the dry and the rainy season. Acta Zool, 190: 11-16.

1993, Vertical distribution and Abundance of pseudosc orpions(Arachnida) in the soil of two different neotropical primary forests during the dry and rainy seasons. Memoirs of the Queensland Museum, 33(2): 431-440.

ADIS, J., MAHNERT, V., MORAIS, J. W. \& RODRIGUES, J. M., 1988, Adaptation of an Amazoniaian pseudoscorpion (Arachnida) from dryland forests to inundation forests. Ecology, 69(1): 287-291.

AGUIAR, N. O. \& BÜHRNHEIM, P. F., 1998, Pseudoscorpions (Arachnida) of the Ilha de Maracá. pp. 381-389. In: W. Mlliken \& J. Ratter (ed). Maracá. The Biodiversity and Environment of an Amazoniaian Rainforest. Jon Wiley \& Sons Ltd. England.

AGUIAR, N. O., 2000, Diversidade e História natural de Pseudoscorpiões (Arachnida), em floresta Primária de terra firme, no alto Rio Urucu, Coari, Amazoniaas. Tese de Doutorado, Manaus, INPA/FUA. 225p.

AGUIAR, N. O., BÜHRNHEIM, P. F., 2003, Pseudoscorpiões (Arachnida) da vegetação de sub-bosque da floresta primária tropical de terra firme (Coari, Amazoniaas, Brasil). Acta Amazonica, 33(3): 515-526.

CHAUVEL, A., LUCAS, Y. \& BOULET, R., 1987, On the genesis of the soil mantle of the region of Manaus, Central Amazoniaia, Brazil. Experientia, 43: 234-241.

EIJACKERS, H., 2001, A future for soil ecology? Connecting the systems levels: moving from genomes to ecosystems. Opening lecture to the XIII ICSZ "Biodiversity of soil organisms and ecosystem functioning". Eur. J. Soil Biol. 37: 213-220.

HILTY, J. \& MERENLENDER, A., 2000, Faunal indicator taxa selection for monitoring ecosystem health. Biological Conservation, 92:185-197.

HÖFER, H., MARTIUS, C. \& BECK, L., 1996, Decomposition in an Amazoniaian rain forest after experimental liter addition in small plots. Pedobiologia, 40: 570-576.

HUBBELL, S., AHUMADA, J. A., CONDIT, R. \& FOSTER, R. B., 2001, Local neighborhood effects on long-term survival of individual trees in a Neotropical forest. Ecological Research, 16: 859-875.

LONGINO, J.A., CODDINGTON, J. \& COLWELL, R. K., 2002, The ant fauna of a tropical rain forest estimating species richness three different ways. Ecology, 83(3): 689-702.

LUIZÃO, F. J. \& SCHUBART, H. O. R., 1987, Litter production and decomposition in a terra-firme forest of Central Amazonia. Experientia, 43: 259-265.

MACDADE, L. A., BAWA, K. S., HESPENHEIDE, H. A. \& HARTSHORN, G. S. (Eds.), 1993, La Selva, ecology and natural hihistory of a neotropical rainforest. Universit of Chicago Press, Chicago, Illinois, USA.

MAGNUSSON, W. \& MOURÃO, G., 2003, Estatística sem matemática. A ligação entre as questões e análise. Editora Planta, Londrina-PR. 126p.

MAHNERT, V. \& ADIS, J., 1985, On the occurrence and habitat of Pseudoscorpions (Arachnida) from Amazoniaian forest of Brazil. Studies on Neotropical Fauna and Environment, 20(4): 211-215.

, 2002, Pseudoscorpiones, pp. 367-380. In: J. Adis (ed.). Amazoniaian Arachnida and Myriapoda, 590p., Pensoft Publishers, Sofia - Moscow..

MARQUES-FILHO, A. O., RIBEIRO, M. N. G. \& SANTOS, J. M., 1981, Estudos climatológicos da Reserva Florestal Ducke, Manaus, AM. IV. Precipitação. Acta Amazoniaica, 4: 759-768.

MAY, R. M., 1994, The effects of spatial scale on ecological questions and answer. pp. 1-17. In: P. J. Edwards, R. M. May, N. R. Webb (eds.), Large scale ecology and conservation biology, 375p. Blackwell Science.

MORAIS, J. W., 1985, Abundância e distribuição vertical de Arthropoda do solo numa floresta primária não inundada. Dissertação de Mestrado, Manaus, INPA/FUA, 92p.

MORAIS, J. W., ADIS, J., MAHNERT, V., BERTI-FILHO, E., 1997, Abundance and phenology of Pseudoscorpiones (Arachnida) from a mixed water inundation forest in Central Amazonia, Brazil. Revue Suisse Zool. 104(3): 475-483.

RANZANI, G., 1980, Identificação e caracterização de alguns solos da Estação Experimental de Silvicultura Tropical do INPA. Acta Amazonica, 24: 19-30.

RIBEIRO, J. E. L. S., HOPKINS, M. J. G., VICENTINI, A., SHTHERS, C. A., COSTA, M. A. S., BRITO, J. M., SOUZA, M. A. D., MARTINS, L. H. P., LOHMANN, L. G., ASSUNÇÃO, P. A. C. L., PEREIRA, E. C., SILVA, C. F., MESQUITA, M. R. \& PROCÓPIO, L. C., 1999, Flora da Reserva Ducke: Guia de identificação das plantas vasculares de uma floresta de terra-firme na Amazônia Central. INPA, Manaus. 816p.

STRAALEN, N. M., 1998, Evaluation of bioindicator systems derived from soil arthropods communities. Applied Soil Ecology, 9: 429-437. 